\title{
Analysis of Marketing Margins, Dry Garden Products in Iran
}

\author{
Seyed Mohammad Reza Akbari \\ Islamic Azad University, Marvdasht Branch, Marvdasht, Iran \\ Mahla Zare Mehrjerdi \\ Tehran University, Tehran, Iran
}

\begin{abstract}
Agricultural sector is one of the economic sectors that always had a considerable impact on the country's export. The garden between products and facilities due to capacity and the relative advantage in the production always plays an important role in the non-oil export. The aim of these studies of economic issues, is to analyze the major marketing dried fruit (pistachio, almond rock, walnuts, and walnut) in Fars province. In this study, information and statistics needed were collected through interviews with experts and Agriculture Organization of Fars province. For this purpose the method used in this study is commonly used in economic texts and retail margins and wholesale agents and share marketing costs with the market ratio. The results of this study indicate that factor market costs for pistachio, almonds, walnuts and Mghzgrdv are 30.340, 21.167, 16.794 and 17.061.
\end{abstract}

Keywords: marketing, dried fruits, Fars province

\section{Introduction}

Agriculture plays an essential role in Gulf security and employment, production and food security and the country had a major share of GDP allocated to will. This section provides the raw materials for other sectors, and agriculture caused the boom in this section. In Fars province about $23.7 \%$ of the employed population are engaged in agricultural activities, that province is the most important part of comprehensive agricultural and economic activities.

The province has productive capacity potential in the production of horticultural crops and it is one of the largest producing horticultural crops considered the nuts almonds, walnuts and pistachios from the capacity of high production. About 22 percent of total Gardens Fars province is under cultivation of non-fertile Zyrksht that is over 63,391 hectares and the fertile is about 283,623 hectares, and the rest of the Gardens is under cultivation of almond (blue and dry) as the largest producer of the country with level of cultivation over 35,571 hectares and production levels about 27,635 tons and the share of 25.4 percent of the country's production.

Pistachio nuts and other gardening products, are capable of including the cultivation of Fars province with over 7,925 and 17,595 hectares respectively with an annual production rate of 25,791.5 and 9,773.3 tons of third

Seyed Mohammad Reza Akbari, Member of young researchers club and graduate student of Agricultural Economics, Islamic Azad University, Marvdasht Branch.

Mahla Zare Mehrjerdi, graduate student of Entrepreneurship Management, Entrepreneurship Faculty, Tehran University.

Correspondence concerning this article should be addressed to Seyed Mohammad Reza Akbari. E-mail: mohammadakbari84@yahoo.com. 
and fourth ranking country.

Reviewing the different studies(outside and inside) about marketing of agricultural products is as follows:

Katryl (2001) examined milk marketing issues in the UK. The results showed that the retail price of this product due to high gross profit has increased five times.

Soltani et al. (1986) determined the profit retail fresh fruit and vegetables and some basic products, by using the relation between the retail and wholesale agricultural product for 23 earned. The result of these studies showed that between 90 to 96 percent of retail price changes in wholesale prices. Also, a percentage change in wholesale prices,makes change in retail price between 1.05 and 1.56 percent.

Shirvanian and Najafi (1999) examined Tomato marketing issues in the city of Fasa, Fars Province and believed that there are several problems between the marketing function and the prices. Groups in marketing organizations that appear to cause awareness of market conditions and prices into a descriptive system of product marketing and market dominance in Akhnyar and in turn.

Torkamani (2000) in his study analyzed and evaluated the production and marketing of saffron in Iran. The results showed that wholesale margins, retail margins and marketing margins of one kilogram of saffron, are respectively 410, 483 and 893 thousand Rials. Coefficient marketing costs for saffron is 20.4 percent and feed costs also marketing of saffron about 30.2 percent.

Salami (2001), considered marketing of pistachio in Yazd province. The results show that the system is not efficient in marketing of pistachio. The service was conducted on this product mainly by producers and the lowest sales and services by major retailers have been made.

The main objectives of this research are as follows:

(1) Economic analysis marketing dried fruits (pistachios, walnuts, almonds) in Fars province;

(2) Determining the wholesale margin, retail margin and total marketing;

(3) Reviewing existing challenges on the way of the manufacturers and processors of this product.

\section{Cases and Methods}

Marketing concept is very vast, and in Economic Sciences it has various definitions that each of them represents the viewpoints of different people in different places and at different time. However, a general definition of marketing includes various stages of processing, packaging, transportation and warehousing, which increased the value of the product passing through each of these steps (Hosseini, 2005).

But marketing of agricultural products due to specific characteristics of these products, including Fsadpzyry, planting and harvesting time limits is different from market of other products, such as industrial products. Accordingly, all operations, including marketing of agricultural products and services on the stage of producing decision until the desired product to reach consumers, have been affected. Thus, agricultural marketing research requires knowledge of relatively large agricultural sciences and economic sciences. Agricultural marketing system produced within the country not only to distribute, but also to develop a permanent international experience.

Marketing activities of agricultural products are divided generally into two categories: transaction and physical facilities. All commutative operations activities include buying and selling products. Physical activities, storage, conversion and transport, including facilities and activities are involved, such as grading, packaging and certification standards and the products. 
General issues of marketing agricultural products in this area occur, using statistics, especially price and calculate various measures. One of the most used criteria in the field of marketing agricultural products is marketing margins. Agricultural marketing margins is defined as the price difference between the price that consumer pays and the farmer receives. Thus, the main criterion to determine total marketing margin between the price received by producers is prices paid by final users.

Marketing margins is like relationship (1) that the retail price and the price difference is achieved by Srmzrh.

$$
M_{t}=P_{r}-P_{f}
$$

Total marketing margins are includes two parts wholesale margins and retail margins. Margins included wholesale price difference between wholesale prices and producer prices or as Srmzrh is expressed in relationship (2):

$$
M_{w}=P_{w}-P_{f}
$$

Retail margins in the retail price displayed difference between the receiver and wholesale, and it can be related as equation (3).

$$
M_{t}=P_{r}-P_{f}
$$

The total marketing margin can define relationship displayed types as related to market margins:

$$
M_{w}=P_{w}-P_{f}
$$

Relationship (4) shows that total retail and wholesale margins, marketing margins are created.

Including the criteria applied in the field of marketing agricultural products market, the cost factor can be cited. Coefficient shows that the market cost of a few percent of the retail price of each product is related to the marketing agents. For the cost, we can use coefficient that can be related to the market (see equation (5)).

$$
R=\left(P_{r}-P_{f}\right) / P_{r} \times 100
$$

One of the key points in marketing studies is to determine the contribution of each marketing factors, including manufacturer, wholesaler and retailer. Relations needed to calculate the market share of each factor are as follows:

$$
\begin{gathered}
M_{r}=P_{r}-P_{w} \\
M_{t}=M_{r}-M_{w} \\
R=\left(P_{r}-P_{f}\right) / P_{r} * 100
\end{gathered}
$$

The above relations (5)-(8), are the share of producers, large share sales, and the share of retail sales.

\section{Results and Discussion}

In this study, information and statistics needed Bakarshnasan was collected through interviews and Agriculture Organization of Fars province (see Table 1).

Based on the results of profit intermediaries and agents, marketing their remarkable portion is based on results in Table 2 for pistachio where wholesaler margin equals to 21,800 Rials, margins and retailer margins entire are 32,667, 10,867 Rials and has been provided share of pistachio production factors. Producers share more of a stake sale and retail sale. Eighty nine point six six percent is share of producers, and the major share of it is 20.24 percent and 30.02 percent share of retail and marketing costs pistachio coefficient is about 30.34, which represents 30.34 percent of the price-related factors pistachio marketing (see Figure 1). 
Table 1

Average Price of Wholesalers, Retailers and Producers

\begin{tabular}{lccr}
\hline \multirow{2}{*}{ Type of crop } & \multicolumn{2}{c}{ Price sale } \\
\cline { 2 - 4 } & Producer & Wholesaler & Retailer \\
\hline Pistachio & 75,000 & 96,800 & 107,667 \\
Almond & 13,500 & 15,188 & 17,125 \\
Walnut & 45,000 & 47,250 & 54,083 \\
Kernel walnut & 105,000 & 112,300 & 126,600 \\
\hline
\end{tabular}

Note. Source: Organization of Fars Province Jhadkshavrzy, 2009.

Table 2

Margin Markets, Marketing Factors and Factor Cost Share Market

\begin{tabular}{lcc}
\hline Description & Pistachio & Walnut \\
\hline Wholesaler margin & 21,800 & 2,250 \\
Margin retailer & 10,867 & 6,833 \\
Total margin & 32,667 & 9,083 \\
Ration producer & 89.906 & 87.365 \\
Ration wholesaler & 20.24 & 4.1 \\
Ration retailer & 30.2 & 21.1 \\
Marketing cost index & 30.340 & 16.794 \\
\hline
\end{tabular}

Note. Source: Research findings.

Based on the results in Table 2 walnut wholesaler margin against is 2,250 RLS, RLS 6,833 retail margins and total margins is 9,083 Rials and cost factor in product marketing for walnut is 16,794, 16,794 Bashdkh that shows marketing percent of sales price for walnut factor .

Figure 1 and Figure 2 best represent the subject.

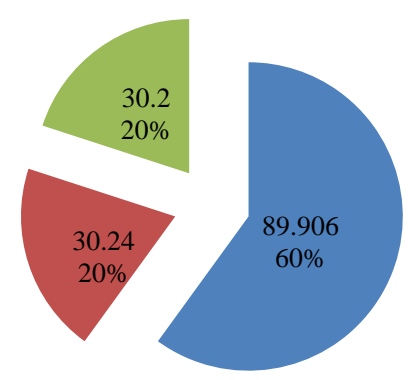

Figure 1. Producers share, stake sale and retail sale of pistachio.

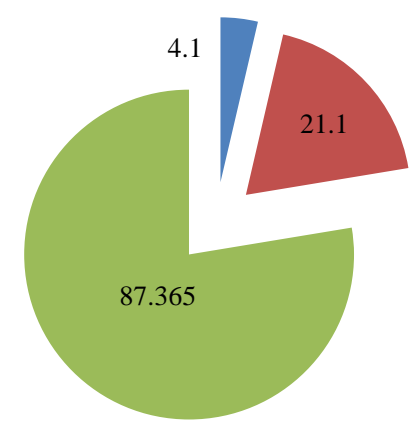

Figure 2. Producers share, stake sale and retail sale of walnut. 
The results in Table 3 show that margins for major product sales and almond stone are 1,688 RLS 7,300 RLS nuts. Retail margins and total margins for the product and almond stone nuts, are respectively 1,937, 3,625 and 14,300 Rials, and total margine for Kernel walnut is 21,600 Rials. For both product and part manufacturers of major share of retail sales and more are respectively 88.689, 88.704 percent. Almond stone product for the major share of the retail sales is higher than 9.8 percent and the share of wholesaler and retailer shares are 21.1 percent (see Figure 3).

Cost coefficient for product marketing of almond stone is equal to 21.167, which represents 21.167 percent of the sales price of almond rock related to the marketing agents, and marketing expense ratio nuts is equal to 17.061 and the percent of the expression of brain price Walnut Marketing for related factors is 17.61.

Table 3

Margin Markets, Marketing Factors and Factor Cost Share Market

\begin{tabular}{lcc}
\hline Description & Almond & Kernel walnut \\
\hline Wholesaler margin & 1,688 & 7,300 \\
Margin retailer & 1,937 & 14,300 \\
Total margin & 3,625 & 21,600 \\
Ration producer & 88.689 & 88.704 \\
Ration wholesaler & 9.8 & 5.7 \\
Ration retailer & 21.1 & 17 \\
Marketing cost index & 21.167 & 17.061 \\
\hline
\end{tabular}

Note. Source: Research findings.
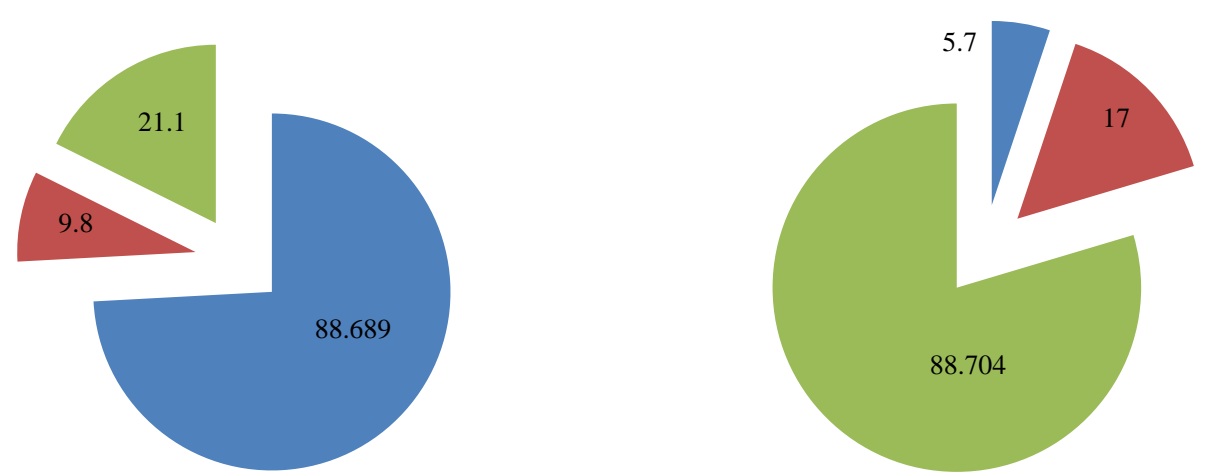

Figure 3. Producers share, stake sale and retail sale almond and kernel walnut.

\section{Offers}

Based on the study results and information collected it can be presented the following proposals:

(1) Executive solutions and suggestions;

(2) Development efforts in basic agricultural insurance products, garden, livestock;

(3) Secure investment, when agriculture sector reforms and elimination of legal restrictions is happened;

(4) Organizing the market and adoption of appropriate supportive policies comprehensive;

(5) Increasing the share of credit facilities and agricultural sector and making it commensurate with the share of agricultural products compared to other provinces;

(6) Ceating gardens efficiency in the land Shybdarkm;

(7) Increasing mechanization coefficient. 


\section{References}

Cottril, R. (2001). Testimony on the impact of northeast dairy compact channel pricing strategies on the performance of the new England industry. Food Policy, Issue Paper, England.

Hosseini, S., \& Ghalandari, M. (2005). Analysis of marketing margins saffron Iran. Selected Proceedings of the 6th Conference of Agricultural Economics Iran. Mashhad, Iran (in Persian).

Kohls. R. I. (1961). Marketing of agricultural products. New York: Macmillan publishing company.

Salami, H. (2001). Marketing issues in Yazd pistachio. Pistachio Proceedings of the Country’s First Festival, 5(3), 110-92 (in Persian).

Shepherd, G. S., \& Futrell, G. A. (1969). Marketing farm products. Iowa, USA: State University Press.

Shirvanian, A., \& Najafi, B. (1999). Marketing of tomato in Fars province. Journal of Economics. Agriculture and development, 26, 23-31 (in Persian).

Soltani, G. H., Torkamani, J., \& Zarnegar, D. (1986). How to determine the retail fruit and Trhbar powder and some basic products in Shiraz. Journal of Agricultural Sciences, 17 (in Persian).

Torkamani, J. (2000). Economic analysis of production, technical efficiency and marketing of saffron. Journal of Science and Technology of Agriculture and Natural Resources, 4(3), 29-44 (in Persian). 